\title{
Scalable and Template-free Aqueous Synthesis of Zirconium-based Metal-Organic Frameworks Coating on Textile Fiber
}

\author{
Kaikai Ma, ${ }^{\dagger} \star$ Timur Islamoglu, ${ }^{\star}$ Zhijie Chen, ${ }^{\star}$ Peng Li, ${ }^{\star}$ Megan C. Wasson, ${ }^{*}$ Yongwei Chen, ${ }^{\star}$ \\ Yuanfeng Wang, ${ }^{\dagger}$ Gregory W. Peterson, ${ }^{\#}$ John H. Xin ${ }^{*, \dagger}$, and Omar K. Farha, ${ }^{*, \ldots, \&}$ \\ 'Research Centre for Smart Wearable Technology, Institute of Textiles and Clothing, The Hong Kong \\ Polytechnic University, Hong Kong SAR 999077, China \\ *Department of Chemistry and International Institute of Nanotechnology, ${ }^{\&}$ Chemical and Biological \\ Engineering Northwestern University, 2145 Sheridan Road, Evanston, Illinois 60208, United States \\ "U.S. Army Combat Capabilities Development Command Chemical Biological Center, 8198 Blackhawk Road, \\ Aberdeen Proving Ground, MD 21010
}

\begin{abstract}
Organophosphonate-based nerve agents, such as VX, Sarin (GB) and Soman (GD), are among the most toxic chemicals to humankind. Recently, we have shown that Zr-based metal-organic frameworks (Zr-MOFs) can effectively catalyze the hydrolysis of these toxic chemicals for diminishing their toxicity. On the other hand, utilizing these materials in powder form is not practical, and developing scalable and economical processes for integrating these materials onto fibers is crucial for protective gear. Herein, we report a scalable, template-free and aqueous solution-based synthesis strategy for the production of Zr-MOFs coated textile. Among all MOF/fiber composites reported to date, the MOF-808/polyester fibers exhibit the highest rates of nerve agent hydrolysis. Moreover, such highly porous fiber composites display significantly higher protection time compared to its parent fabric for a mustard gas simulant, 2-chloroethyl ethyl sulfide (CEES). A decreased diffusion rate of toxic chemicals through the MOF layer can provide time needed for the destruction of the harmful species.
\end{abstract}




\section{Supporting Information}

\section{Instrumentation}

Powder X-ray diffraction (PXRD) patterns of fiber substrates and MOFs/fiber composite were recorded at room temperature on a STOE-STADIMP powder diffractometer equipped with an asymmetric curved Germanium monochromator ( $\mathrm{CuK} \alpha 1$ radiation, $\lambda=1.54056 \AA$ ) at IMSERC (Integrated Molecular Structure Education and Research Center) of Northwestern University. $\mathrm{N}_{2}$ adsorption and desorption isotherms of all materials were tested on a Micromeritics Tristar (Micromeritics, Norcross, GA) instrument at $77 \mathrm{~K}$. Scanning electron micrographs (SEM) images of all coating were taken using a Hitachi SU8030 at the EPIC facility (NUANCE CenterNorthwestern University). Before SEM observation, all samples were coated with OsO4 to $\sim 9 \mathrm{~nm}$ thickness in a Denton Desk III TSC Sputter Coater. Inductively coupled plasma-optical emission spectroscopy (ICP-OES) was tested using an iCAPTM 7600 ICP-OES Analyzer (Thermo Scientific ${ }^{\mathrm{TM}}$ ) over the $166-847 \mathrm{~nm}$ spectral range. NMR spectra were collected on $400 \mathrm{MHz}$ Agilent DD MR-400 at IMSERC (Integrated Molecular Structure Education and Research Center) of Northwestern University.

\section{Materials}

$\mathrm{ZrOCl}_{2} \cdot 8 \mathrm{H}_{2} \mathrm{O}(98 \%)$, benzene-1,3,5-tricarboxylic acid (BTCA, 98\%), 2-aminoterephthalic acid $\left(\mathrm{H}_{2} \mathrm{BDC}-\mathrm{NH}_{2}, 99 \%\right)$, acetic acid, formic acid, and trifluoroacetic acid (99\%) were purchased from Sigma-Aldrich. Other chemicals were purchase Fisher Chemical. Deionized water was used as the water source throughout the experiments. PET fabric (thickness: $120 \mu \mathrm{m}$ ) was provided by China Dyeing holdings Ltd., Hong Kong. Before using, PET fabric samples were scoured in a $3 \% \mathrm{NaOH}$ water solution at $90{ }^{\circ} \mathrm{C}$ for $20 \mathrm{~min}$ to remove impurities, and the $\mathrm{NaOH}$ residue on fabric was removed by thorough water washing. Polypropylene (PP) fiber is separated from the inner layer of a 3M N95 mask. Polyacrylonitrile (PAN) nanofiber was prepared by electrospinning at $10 \mathrm{kV}$ with a tip-tocollector distance of $15 \mathrm{~cm}$. A $10 \%$ solution of PAN dissolved in N,N-dimethylformamide (DMF) was used as the electrospinning solution. 


\section{Synthesis of MOF-808 coating on fiber}

Four pieces of PET textile ( $4 \mathrm{~cm} \mathrm{x} 4 \mathrm{~cm}$ ), BTCA ( $2 \mathrm{mmol}, 0.42 \mathrm{~g}$ ) and $\mathrm{ZrOCl}_{2} \cdot 8 \mathrm{H}_{2} \mathrm{O}(4.5$ mmol, $1.45 \mathrm{~g})$ were added to a mixture of DI water $(20 \mathrm{~mL})$ and TFA $(10 \mathrm{~mL})$ in a sealed $80 \mathrm{~mL}$ Pyrex Schott bottle. After sonication for $0.5 \mathrm{~h}$, the mixture was placed place in an oven at $100{ }^{\circ} \mathrm{C}$ for $2 \mathrm{~h}$. After cooling down to room temperature, the obtained fabric samples were immersed in $100 \mathrm{~mL}$ hydrochloric acid/acetone solution (volume ratio of 1: 99) for $24 \mathrm{~h}$ at $50{ }^{\circ} \mathrm{C}$, and then washed by deionized water $(2 \times 50 \mathrm{~mL})$, acetone $(3 \times 50$ $\mathrm{mL})$. Finally, the samples were dried at room temperature, and activated at $110{ }^{\circ} \mathrm{C}$ for 24 $\mathrm{h}$ under vacuum. Caution! Adequate personal protective equipment should be used when handling TFA containing mixtures.

\section{Scale-up synthesis of MOF-808 coating on fiber}

One piece of PET textile $\left(10 \mathrm{~cm}\right.$ x $120 \mathrm{~cm}$ ), BTCA (40 mmol, $8.4 \mathrm{~g}$ ) and $\mathrm{ZrOCl}_{2} \cdot 8 \mathrm{H}_{2} \mathrm{O}$ (90 mmol, $29 \mathrm{~g}$ ) were added to a mixture of DI water $(400 \mathrm{~mL})$ and TFA $(200 \mathrm{~mL})$ in a sealed $1 \mathrm{~L}$ Pyrex Schott bottle. After sonication for $0.5 \mathrm{~h}$, the mixture was placed place in an oven at $100{ }^{\circ} \mathrm{C}$ for $3 \mathrm{~h}$. After cooling down to room temperature, the obtained fabric samples were immersed in $1 \mathrm{~L}$ hydrochloric acid/acetone solution (volume ratio of 1: 99) for $24 \mathrm{~h}$ at $50^{\circ} \mathrm{C}$, and then washed by deionized water $(2 \times 1 \mathrm{~L})$, acetone $(3 \times 1 \mathrm{~L})$. Finally, the samples were dried at room temperature, and activated at $110^{\circ} \mathrm{C}$ for $24 \mathrm{~h}$ under vacuum.

Caution! Adequate personal protective equipment should be used when handling TFA containing mixtures.

\section{Synthesis of UiO-66- $\mathrm{NH}_{2}$ coating on fiber}

Four pieces of PET textile (4 cm x $4 \mathrm{~cm})$, BDCA-NH$_{2}(4.5 \mathrm{mmol}, 0.81 \mathrm{~g})$ and $\mathrm{ZrOCl}_{2} \cdot 8 \mathrm{H}_{2} \mathrm{O}(3 \mathrm{mmol}, 0.97 \mathrm{~g})$ were mixed in DI water $(20 \mathrm{~mL})$ and TFA $(10 \mathrm{~mL})$ in a sealed $80 \mathrm{~mL}$ Pyrex Schott bottle. After sonication for $0.5 \mathrm{~h}$, the mixture was placed place 
in an oven at $100{ }^{\circ} \mathrm{C}$ for $4 \mathrm{~h}$. After cooling down to room temperature, the obtained fabric samples were immersed in $100 \mathrm{~mL}$ hydrochloric acid/acetone solution (volume ratio of 1 : 99) for $24 \mathrm{~h}$ at $50{ }^{\circ} \mathrm{C}$ and then washed by deionized water $(2 \times 50 \mathrm{~mL})$, acetone $(3 \times 50$ $\mathrm{mL}$ ). Finally, the samples were dried at room temperature, and activated at $110^{\circ} \mathrm{C}$ for 24 $\mathrm{h}$ under vacuum.

Caution! Adequate personal protective equipment should be used when handling TFA containing mixtures.

\section{Sample digestion for NMR test}

Fiber composites $(30 \mathrm{mg}$ ) were cut into tinny pieces and put into NMR tube containing $0.95 \mathrm{~mL} \mathrm{D}_{2} \mathrm{O}$ and $50 \mathrm{mg} \mathrm{NaOH}$. After standing for $24 \mathrm{~h}$, the NMR tube was mounted into equipment for ${ }^{1} \mathrm{H}$ NMR or ${ }^{19} \mathrm{~F}$ NMR spectrum collection.

\section{Mass loading determination}

Mass loadings of Zr-MOFs on fiber were calculated based on ICP-OES analysis. All fibrous samples before ICP-OES test were dried under vacuum oven overnight at $100{ }^{\circ} \mathrm{C}$, and $100 \mathrm{mg}$ of composite was quickly weighted and digested in $10 \mathrm{~mL} \mathrm{HNO}_{3} .100 \mathrm{uL}$ of the above solution is diluted into $10 \mathrm{~mL}$ using Milli-Q water for testing the $\mathrm{Zr}$ concentration using ICP-OES method. The mass loading (ML) is calculated as following equation:

$\mathrm{ML}=(\mathrm{C} \times 100 \times 0.01 \mathrm{~L}) /\left(100 \mathrm{mg} \times \mathrm{W}_{\mathrm{Zr}}\right) \times 100 \%$

where $\mathrm{C}$ is the concentration of $\mathrm{Zr}$ in the diluted nitric acid solution measured by ICP-OES, $\mathrm{mg} / \mathrm{L} .100$ is the dilution factor, and $0.01 \mathrm{~L}$ is the volume of concentrated $\mathrm{HNO}_{3}$ used in digestion of fiber composite. $\mathrm{W}_{\mathrm{Zr}}$ is the mass percentage in MOFs: $35.3 \%$ for MOF-808 and $32.8 \%$ for $\mathrm{UiO}-66-\mathrm{NH}_{2}$.

\section{Catalytic hydrolysis test of DMNP}

Catalytic hydrolysis of DMNP experiments were carried out at room temperature and monitored by in situ ${ }^{31} \mathrm{P}$ NMR. All activated MOF/textile samples were cut into tiny pieces $(0.5 \mathrm{~mm} \times 5 \mathrm{~mm})$ and filled into an NMR tube. For comparison of the catalytic 
efficiency of fibers with different MOFs loading, all fiber samples containing the same amount $(1.5 \mu \mathrm{mol})$ of MOFs were added into NMR tube. DMNP ( $4 \mu \mathrm{L} ; 0.025 \mathrm{mmol})$ was dissolved in $0.4 \mathrm{M} \mathrm{N}$-ethylmorpholine solution $(1 \mathrm{~mL} ; 0.05 \mathrm{~mL} N$-ethylmorpholine, 0.9 $\mathrm{mL}$ DI water/0.1 $\mathrm{mL} \mathrm{D}_{2} \mathrm{O}$ ) and transferred into the NMR tube. The tube was vigorously shaken to thoroughly mix the fiber and solution, and rapidly transferred to an NMR

equipment and the ${ }^{31} \mathrm{P}$ spectrum was immediately collected. The first spectrum was recorded $1.5 \mathrm{~min}$ after the start of the catalytic reaction. The extent of the reaction was periodically monitored every $1 \mathrm{~min}$ for $1 \mathrm{~h}$ (number of scans $=16$, delay time $=28 \mathrm{~s}$ ). To assess reaction conversions after removal of fiber, an identical reaction mixture was prepared in a 1.5 dram vial, filtered using a $200 \mathrm{~nm}$ syringe filter at $1.5 \mathrm{~min}$, and filled in an NMR tube for the measurement of conversion by ${ }^{31} \mathrm{P}$ NMR. The catalytic activity of untreated fiber was evaluated under identical conditions and monitored by in situ ${ }^{31} \mathrm{P}$ NMR.

\section{Reusability and stability test}

To test the reusability, the composite sample (6.5\% loading) after catalysis test was washed with $50 \mathrm{~mL}$ deionized for $30 \mathrm{~min}$ and reused in test without drying. The catalytic activity of composite sample (6.5\% loading) after storage for 6 months in air or being stirring (400 $\mathrm{rpm}$ ) for $24 \mathrm{~h}$ in water were also tested to evaluate its durability.

\section{Catalytic hydrolysis test of GD}

Caution! GD is extremely toxic. Experiments should be run by trained personnel using appropriate safety procedures.

Catalytic hydrolysis of GD tests were carried out at room temperature. MOF-808/PET and UiO-66- $\mathrm{NH}_{2}$ PET samples, all containing $1.5 \mu \mathrm{mol}$ MOFs, were filled in a 4-mm glass NMR tube. $1.0 \mathrm{~mL}$ of $\mathrm{H}_{2} \mathrm{O} / \mathrm{D}_{2} \mathrm{O}$ and $50 \mu \mathrm{L}$ of N-ethylmorpholine were then added to the NMR tube to wet the sample. After, $2.5 \mu \mathrm{L}$ of GD $(14 \mu \mathrm{mol})$ was added into the NMR tube, the tube was capped immediately and vigorously shaken to mix the GD and fiber thoroughly in solution. The NMR tube was mounted onto a Varian INOVA 400 NB NMR spectrometer to collect ${ }^{31} \mathrm{P}$ NMR spectra. 


\section{CEES permeation test}

CEES permeation testing was conducted in accordance with ASTM F739-12. A 1.5 in by 1.5 in swatch was sealed in a 1 in diameter glass permeation cell. A countercurrent air flow of $300 \mathrm{~mL} \cdot \mathrm{min}^{-1}$ at $\sim 2 \% \mathrm{RH}$ was applied above and below the swatch. CEES was fed to the swatch at a concentration of $300 \mathrm{mg} \cdot \mathrm{m}^{-3}$. The feed, retentate, and permeate concentrations we monitored using an Agilent 6890 gas chromatograph with a flame ionization detector. Tests were terminated when steady state was reached and the sum of the retentate and permeation concentrations equaled the feed concentration. 


\section{Supporting Images and Tables}

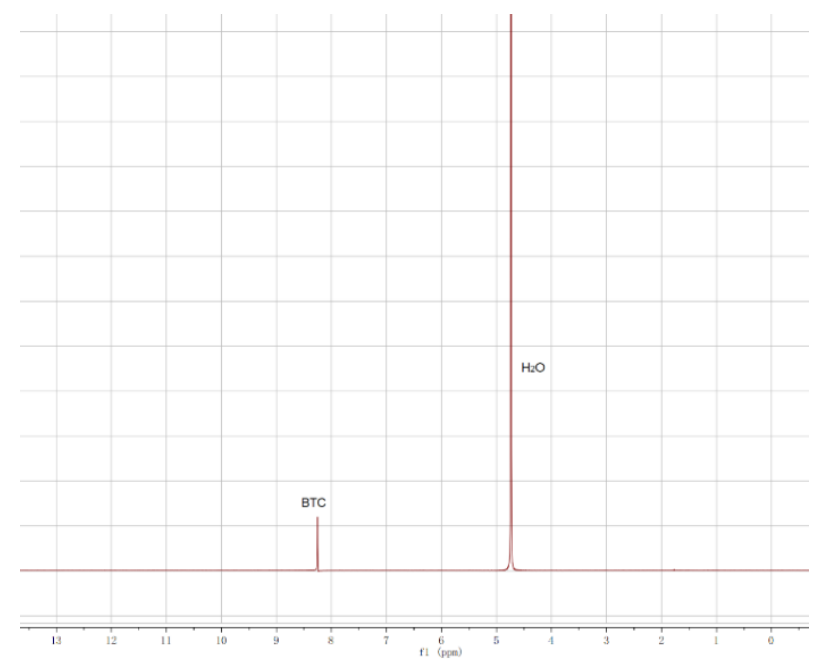

Figure $\mathrm{S} 1 .{ }^{1} \mathrm{H}$ NMR spectrum of sample after 10 min reaction, digested in $5 \% \mathrm{KOH}$ in $\mathrm{D}_{2} \mathrm{O}$.
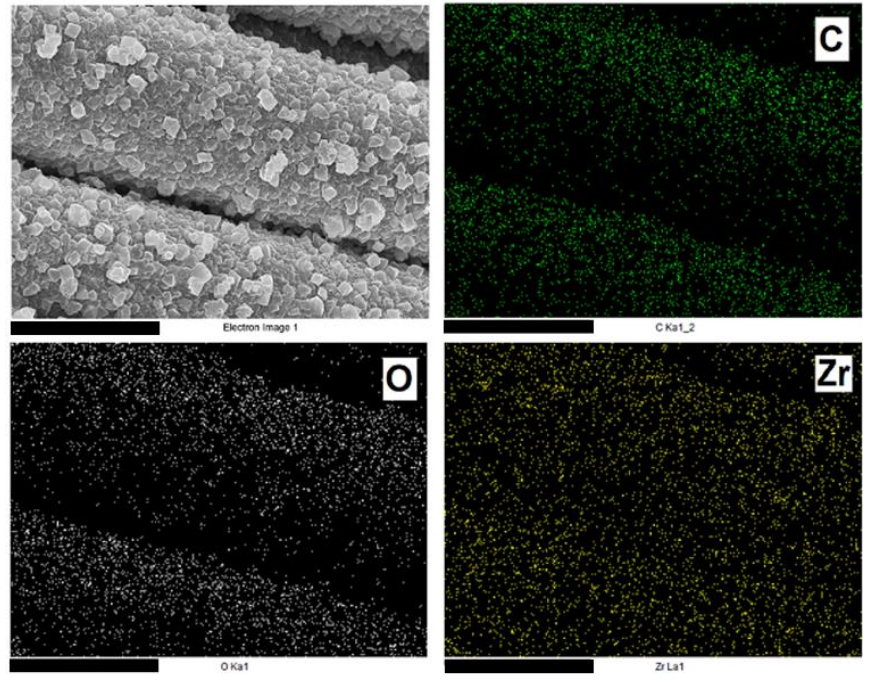

Figure S2. EDX mapping of MOF-808/PET sample; all scale bar: $10 \mu \mathrm{m}$. 


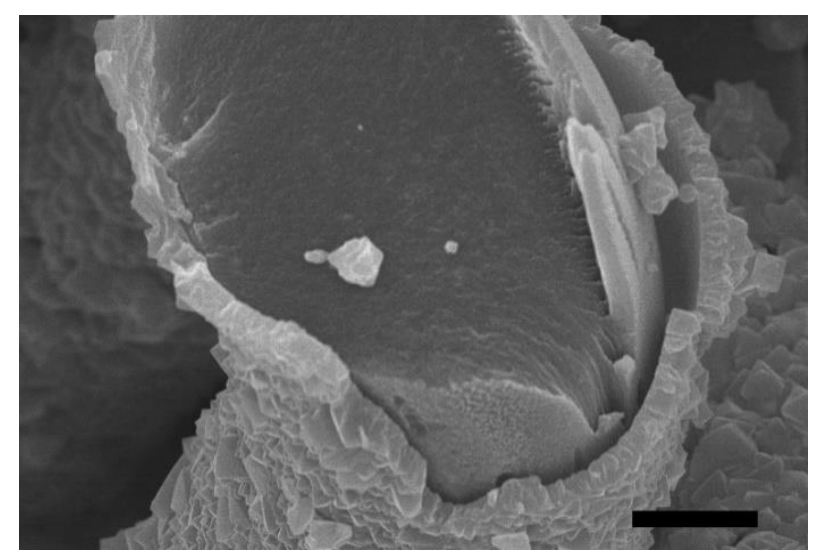

Figure S3. SEM image of MOF-808 coated PET on a cutting edge; scale bar: $5 \mu \mathrm{m}$.

Table S1. Loading and BET surface area summary of the samples

\begin{tabular}{|c|c|l|l|l|}
\hline $\begin{array}{c}\text { Reaction } \\
\text { time (min) }\end{array}$ & Zr element & $\begin{array}{l}\text { MOF-808 } \\
\text { mass loading } \\
(\%)\end{array}$ & $\begin{array}{l}\text { BET surface } \\
\text { area of the } \\
\text { composite } \\
\left(\mathrm{m}^{2} / \mathrm{g}\right)\end{array}$ & $\begin{array}{l}\text { Normalized } \\
\text { BET surface } \\
\text { area of MOFs } \\
\text { coating }\end{array}$ \\
\hline 0 & 0 & & 2 & \\
\hline 10 & 1.8 & & 6 & 710 \\
\hline 20 & 2.1 & 5.8 & 40 & 2150 \\
\hline 30 & 2.4 & 6.5 & 130 & 2160 \\
\hline 60 & 4.5 & 12 & 260 & 2200 \\
\hline 120 & 8.2 & 22 & 480 & \\
\hline
\end{tabular}

Note: ${ }^{\text {a }}$ The MOF-808 mass loading is calculated based on the six connected form (FW: $1551)$.

${ }^{b}$ We hypothesized that all of the zirconium element is from MOF-808 when calculating the normalized BET surface area of MOFs coating. The coating after $20 \mathrm{~min}$ is a mixture of MOF-808 and amorphous gel, indicated by the lower normalized MOF-808 BET surface area. 


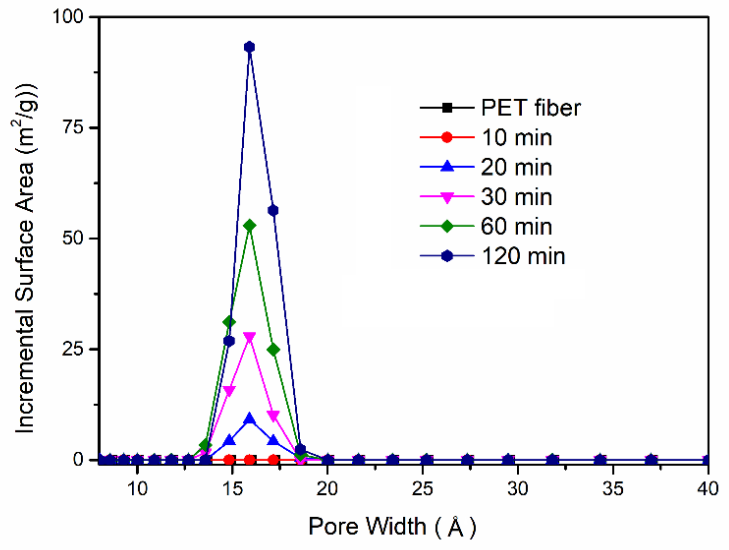

Figure S4. Pore size distribution of MOF-808/PET sample from different reaction time.
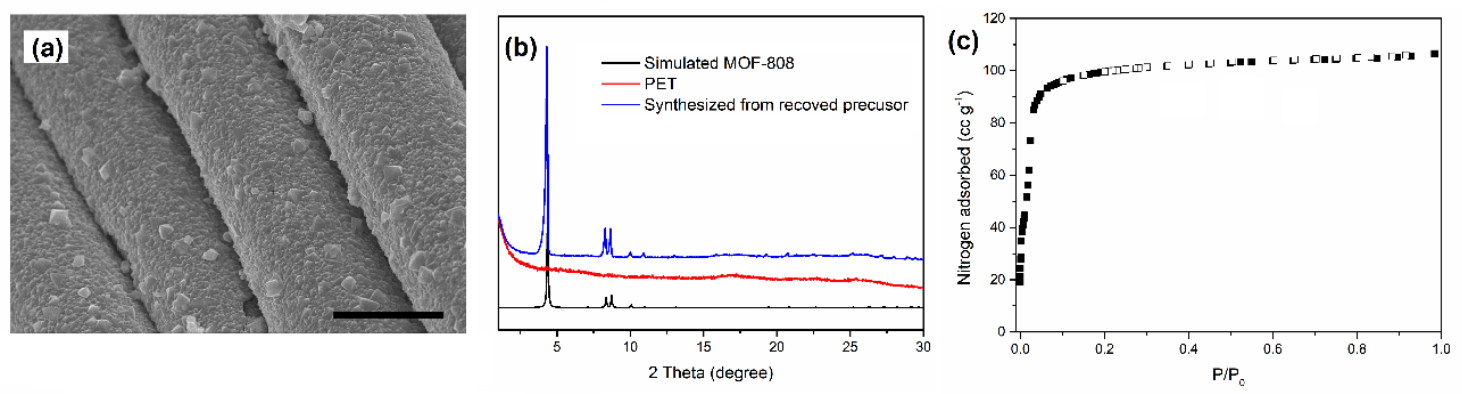

Figure S5. SEM image (a), XRD pattern, and nitrogen sorption isotherm (c) of MOF-808 coated PET sample prepared from reused precursor; scale bar:10 $\mu \mathrm{m}$.
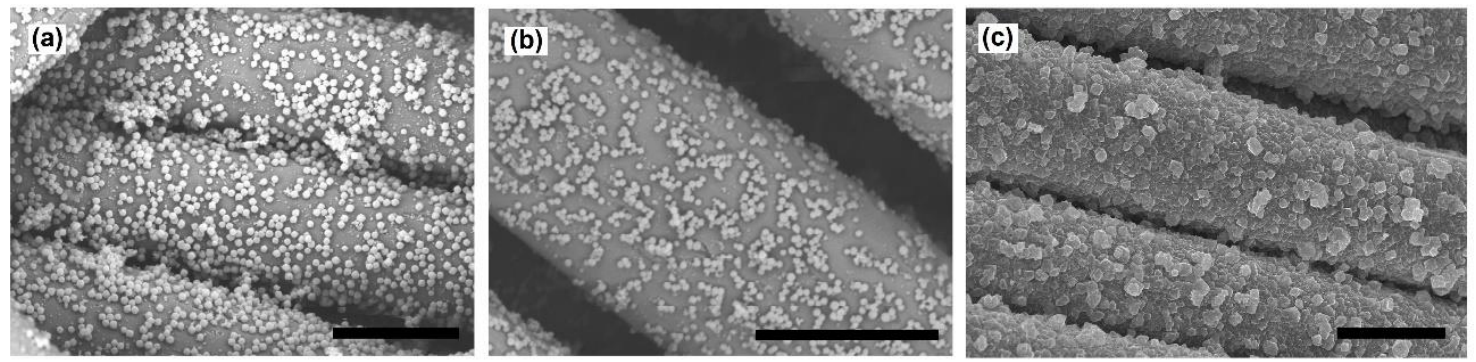

Figure S6. SEM images of MOF-808 coating on PET fiber using 33\% formic acid (a), 33\% acetic acid (b), and 33\% trifluoroacetic acid (c); scale bars: (a-c) $10 \mu \mathrm{m}$. 

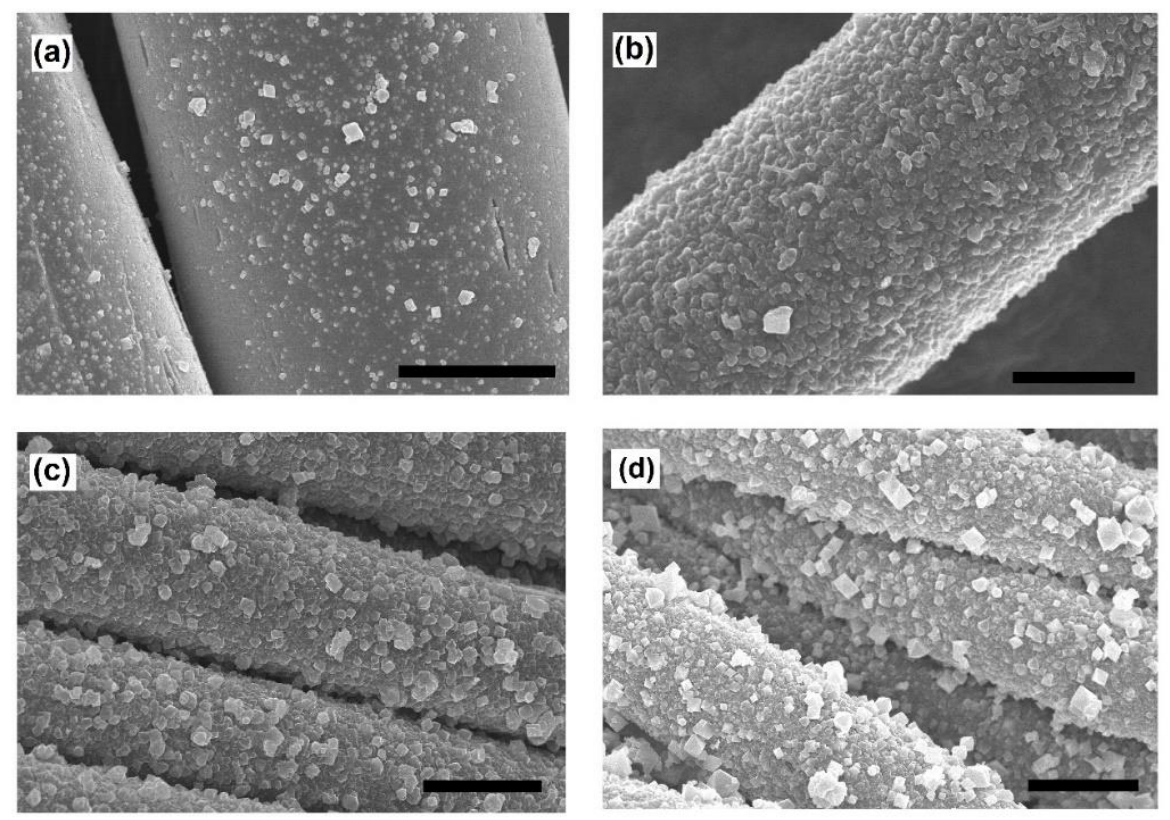

Figure S7. SEM images of MOF-808 coating on PET fiber using 25\% (a), 29\% (b), 33\% (c), and 50\% (d) trifluoroacetic acid as a modulator; scale bars: (a) and (b) $5 \mu \mathrm{m}$, (c) and (d) $10 \mu \mathrm{m}$. 

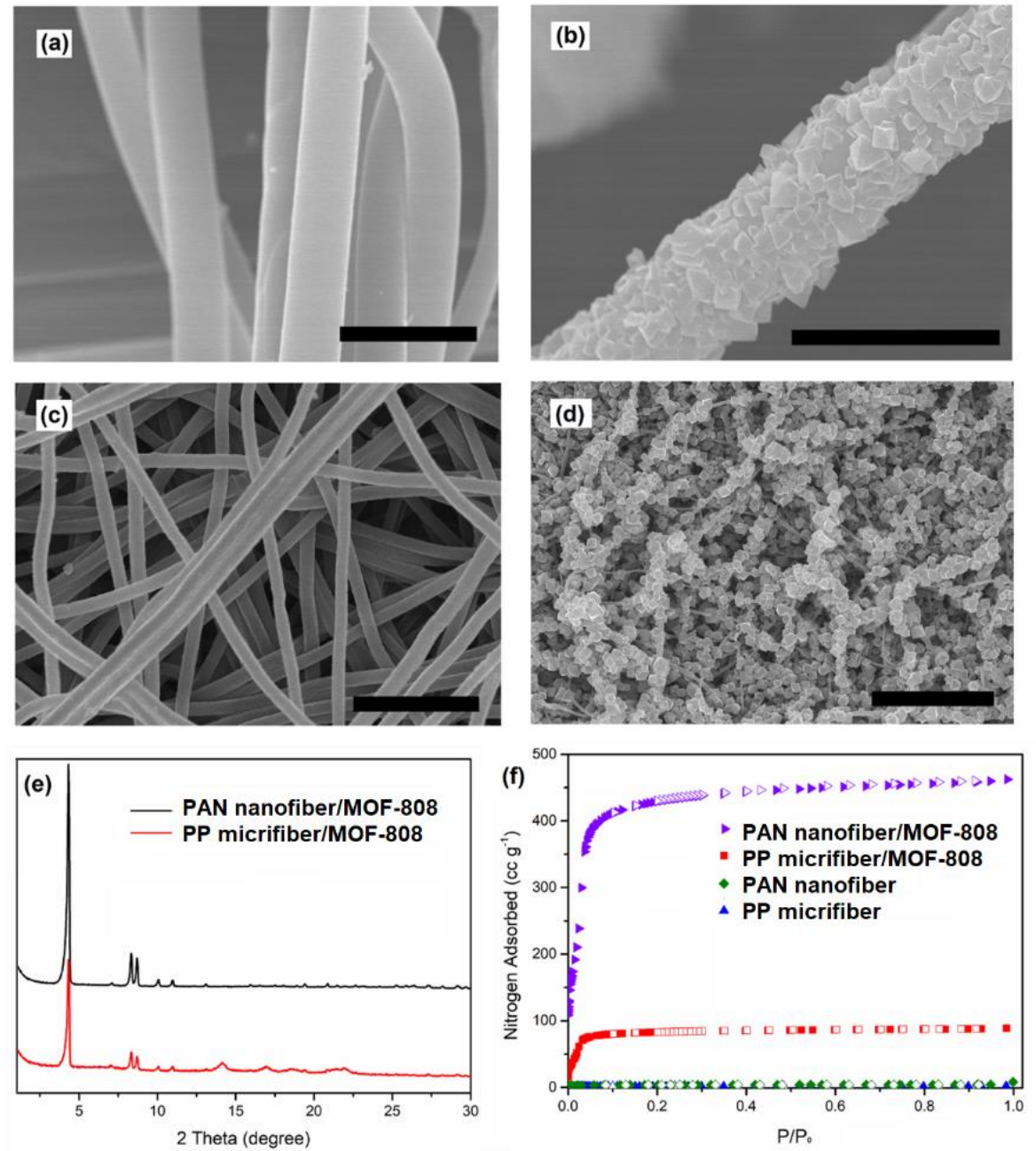

Figure S 8. SEM images of PP fiber (a), MOF-808 coated PP fiber (b), PAN fiber (c), and MOF-808 coated PAN fiber (d). XRD patterns (e) and $\mathrm{N}_{2}$ sorption isotherm (f) of related samples. Scale bare: (a) $10 \mu \mathrm{m}$, (b) $5 \mu \mathrm{m}$, (c) $4 \mu \mathrm{m}$, (d) $10 \mu \mathrm{m}$. 

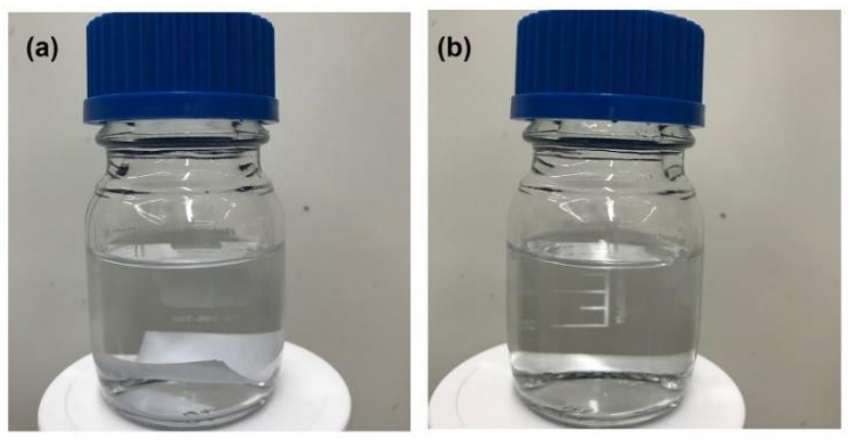

Figure S 9. Optical photographs of PAN nanofiber membrane before (a) and after (b) heating at $130{ }^{\circ} \mathrm{C}$ for $5 \mathrm{~min}$ in a typical MOF-808 synthesis system using DMF as the solvent. The PAN nanofiber mat is totally dissolved in the precursor solution.
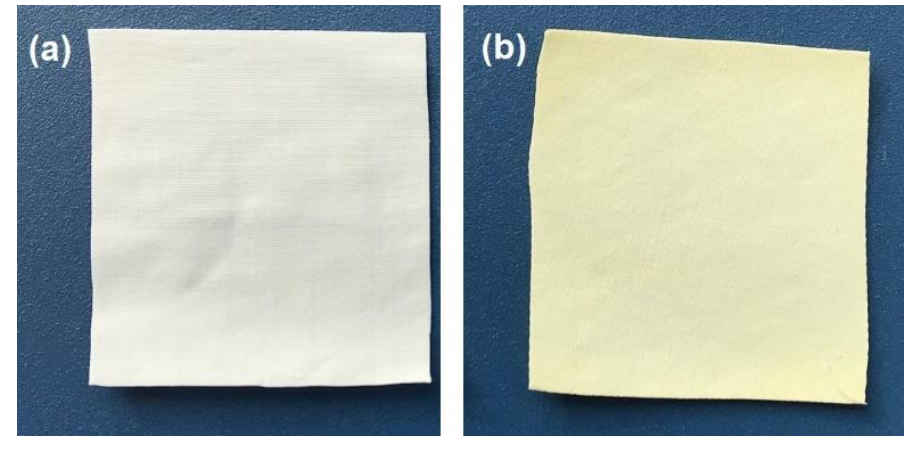

Figure S 10. Optical photographs of PET fabric before (a) and after (b) UiO-66- $\mathrm{NH}_{2}$ coating.

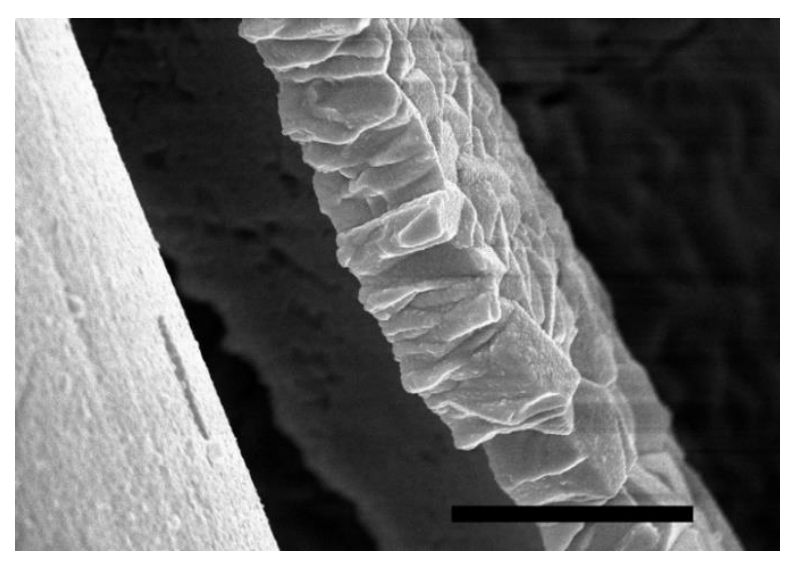

Figure S11. SEM image of UiO-66-NH2 coated PET at the cutting edge; sale bar: $3 \mu \mathrm{m}$. 


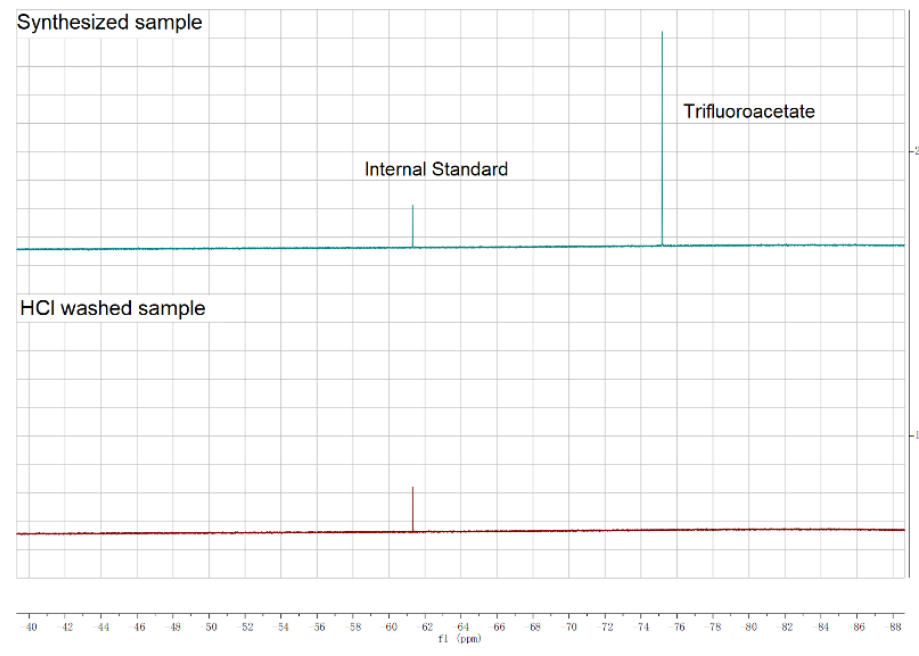

Figure S $12 .{ }^{19} \mathrm{~F}$ NMR spectra of alkaline-digested MOF-808/fiber-TFA before and after $\mathrm{HCl}$ washing. Sample was digested in $5 \% \mathrm{KOH}$ in $\mathrm{D}_{2} \mathrm{O}$, and 1,3-bis(trifluoromethyl)-5bromobenzene was used an internal standard.

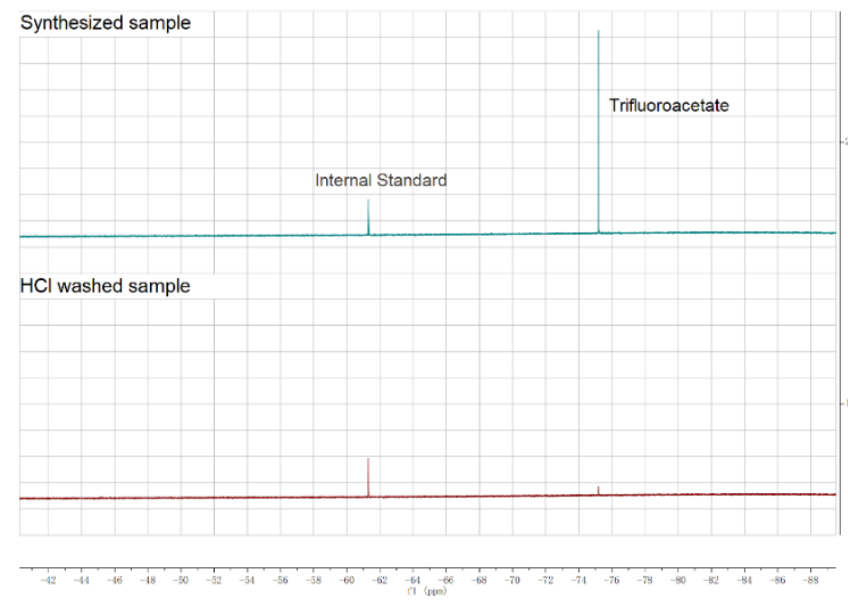

Figure S 13. ${ }^{19} \mathrm{~F}$ NMR spectra of alkaline-digested UiO-66-NH2/fiber-TFA before and after $\mathrm{HCl}$ washing. Sample was digested in $5 \% \mathrm{KOH}$ in $\mathrm{D}_{2} \mathrm{O}$, and 1,3-bis(trifluoromethyl)5-bromobenzene (BTB) was used an internal standard. 


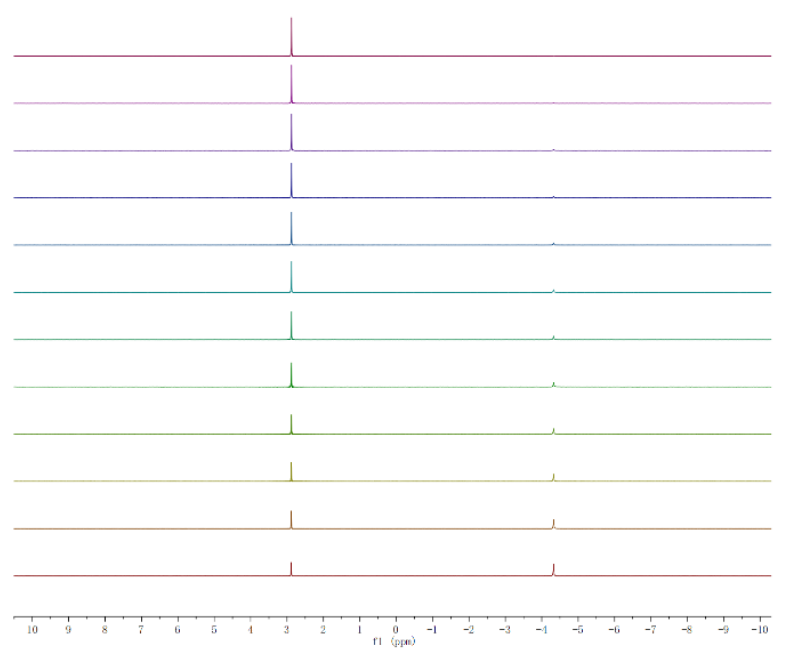

Figure S14. In-situ ${ }^{31} \mathrm{P}$ NMR spectra showing the progress of hydrolysis of DMNP (-4.4 $\mathrm{ppm})$ to dimethoxy phosphate anion $(2.8 \mathrm{ppm})$ in the presence of $10.6 \mathrm{mg}$ of MOF$808_{22} / \mathrm{PET}$. The first spectrum was recorded in $1.5 \mathrm{~min}$, and the interval of each spectrum was $1 \mathrm{~min}$.

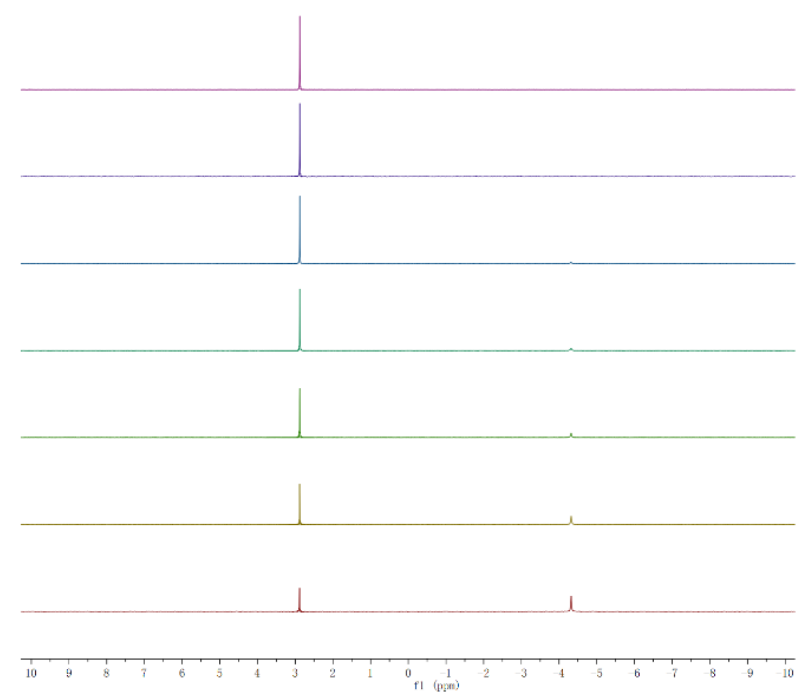

Figure S15. In-situ ${ }^{31} \mathrm{P}$ NMR spectra showing the progress of hydrolysis of DMNP in the presence of $19.4 \mathrm{mg}$ of MOF-808 $12 \% / \mathrm{PET}$. The first spectrum was recorded in $1.5 \mathrm{~min}$, and the interval of each spectrum was $1 \mathrm{~min}$. 


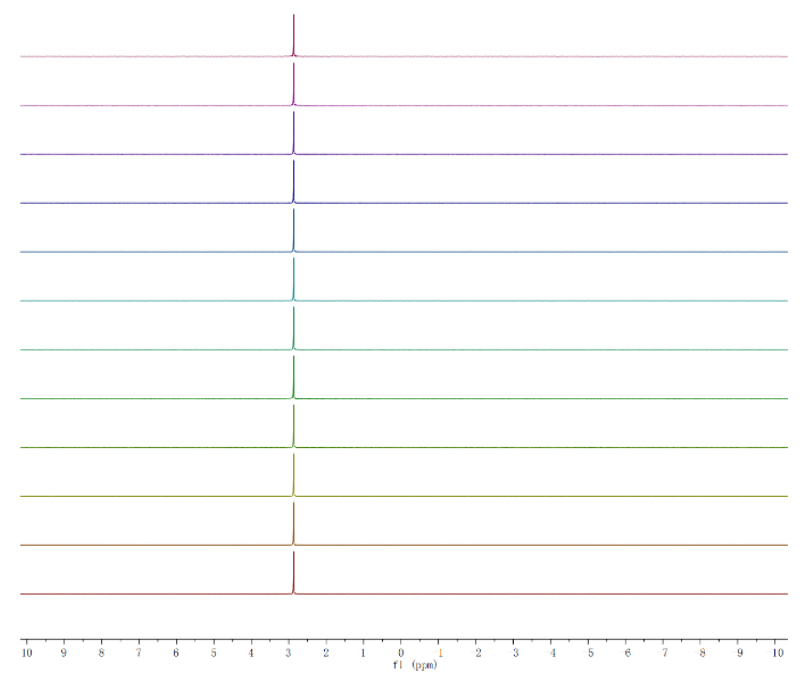

Figure S16. In-situ ${ }^{31} \mathrm{P}$ NMR spectra showing the progress of hydrolysis of DMNP in the presence of $35.8 \mathrm{mg}$ of MOF-8086.5\%/PET. The first spectrum was recorded in $1.5 \mathrm{~min}$, and the interval of each spectrum was $1 \mathrm{~min}$.

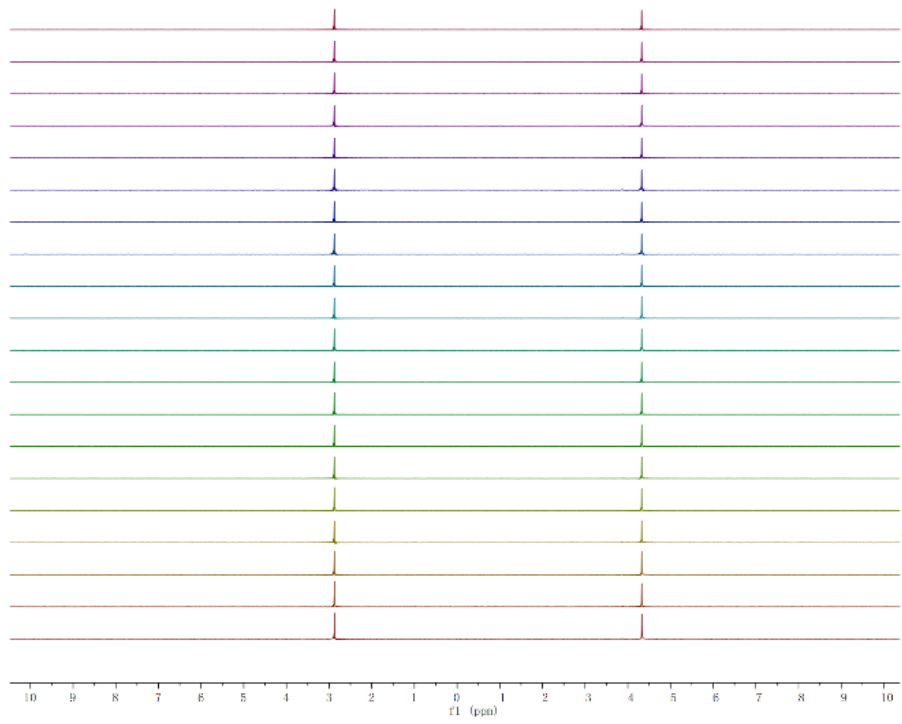

Figure S17. In-situ ${ }^{31} \mathrm{P}$ NMR spectra showing the progress of hydrolysis of DMNP after filtering the MOF-80822\%/PET catalysis. The first spectrum was recorded in $1.5 \mathrm{~min}$, and the interval of each spectrum was $1 \mathrm{~min}$. 

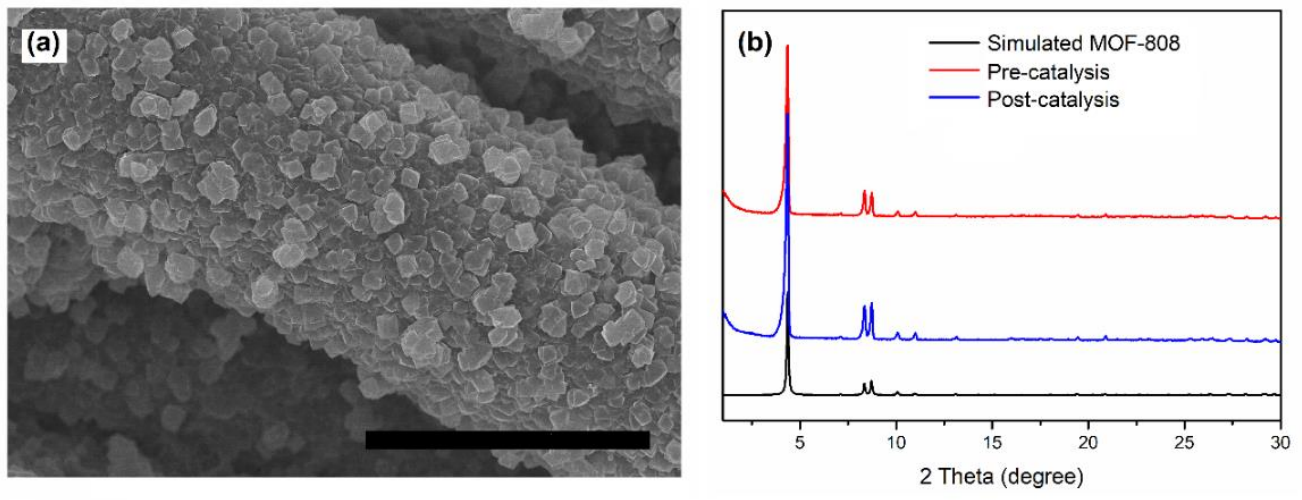

Figure S18. SEM image (a), XRD patterns (b) of the sample after catalysis.

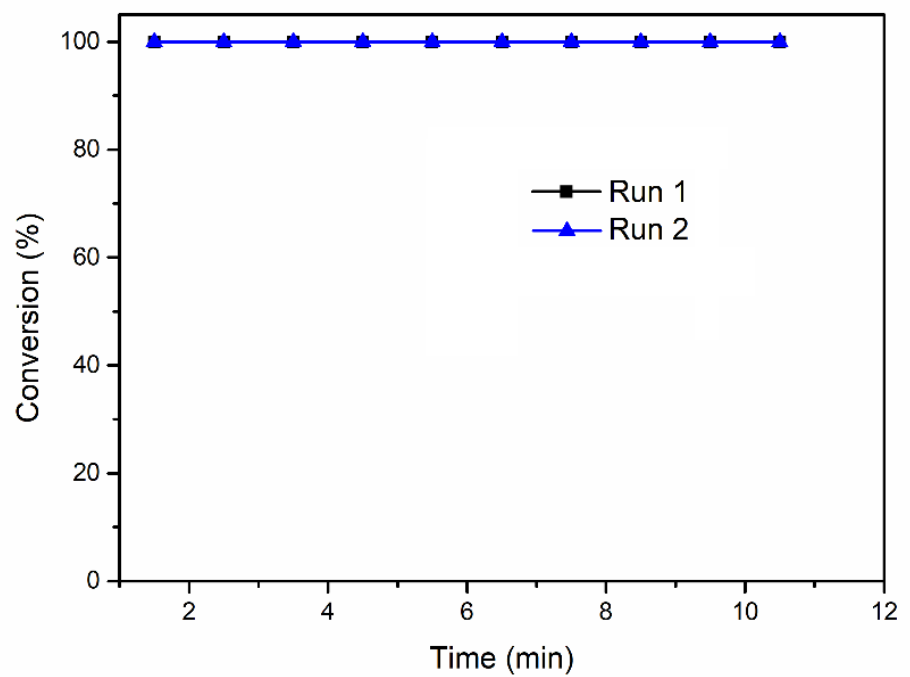

Figure S19. The reusability of the MOF-8086.5\%/PET catalyst. 


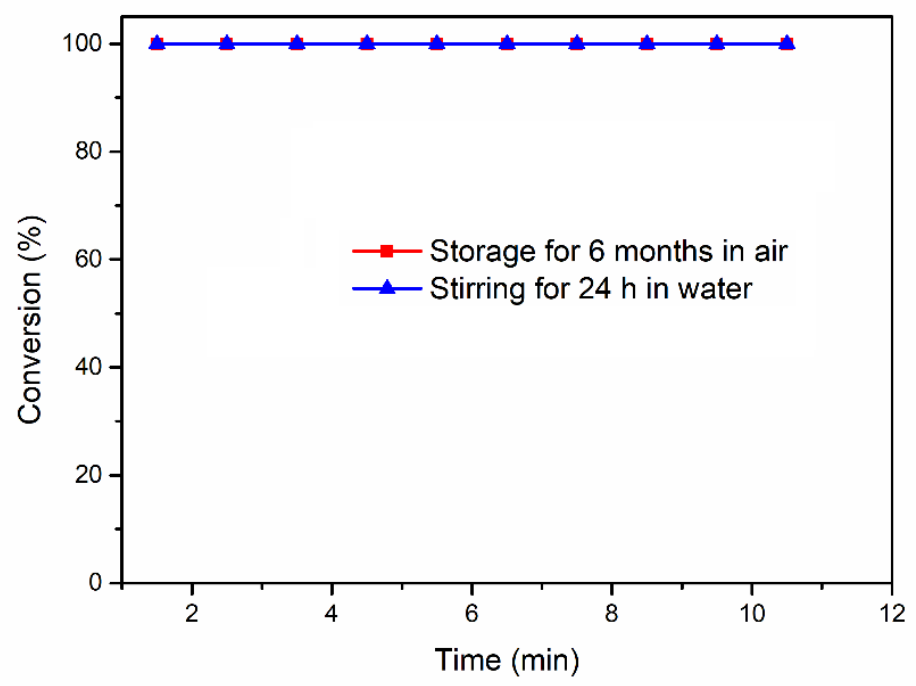

Figure S20. The durability of the MOF-8086.5\%/PET catalyst after storage and stirring test.

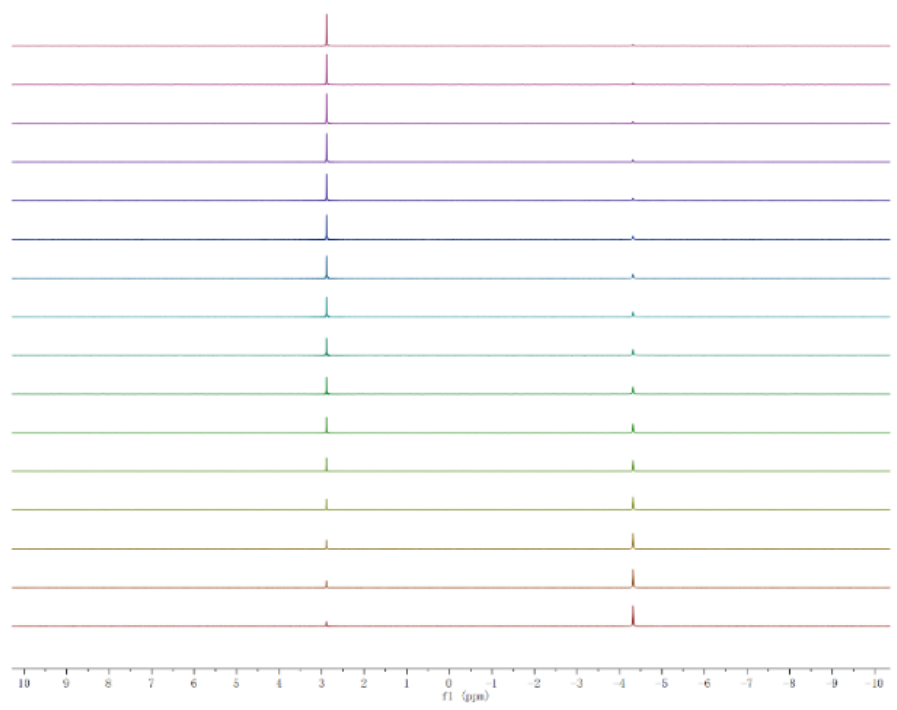

Figure S21. In-situ ${ }^{31} \mathrm{P}$ NMR spectra showing the progress of hydrolysis of DMNP in the presence of $31.5 \mathrm{mg}$ of UiO-66- $\mathrm{NH}_{2-8 \%} \mathrm{PET}$. The first spectrum was recorded in $1.5 \mathrm{~min}$, and the interval of each spectrum was $1 \mathrm{~min}$. 


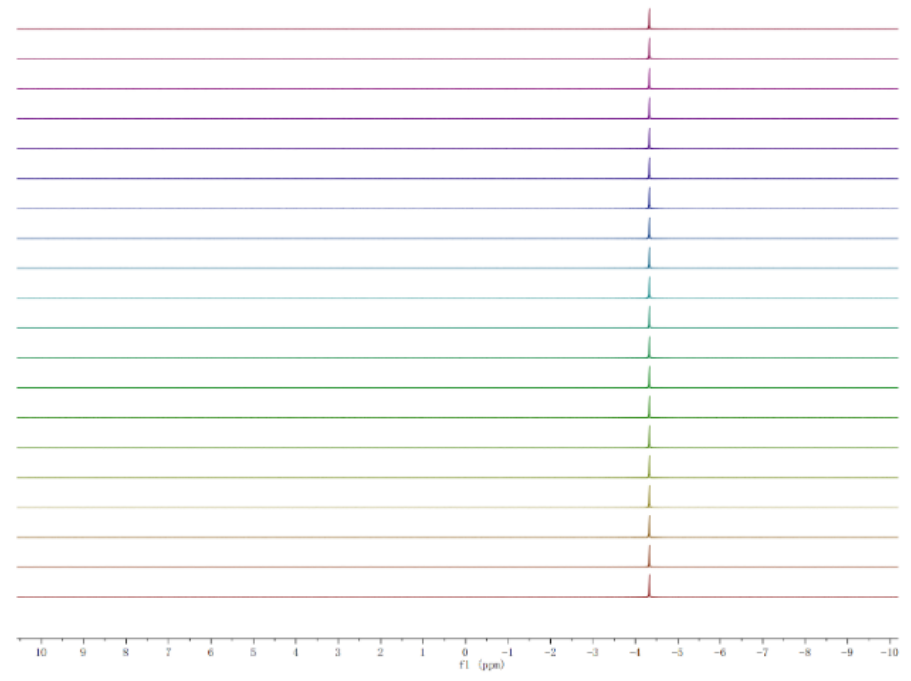

Figure S22. In-situ ${ }^{31} \mathrm{P}$ NMR spectra showing the progress of hydrolysis of DMNP in the presence of $40 \mathrm{mg}$ uncoated PET fiber. The first spectrum was recorded in $1.5 \mathrm{~min}$, and the interval of each spectrum was $1 \mathrm{~min}$.

Table S2. Comparison of materials fabrication methods, properties and catalytic performance of DMNP and GD between this work and recent reported works.

\begin{tabular}{|c|c|c|c|c|c|c|}
\hline Materials & $\begin{array}{l}\text { Synthesis } \\
\text { method }\end{array}$ & $\begin{array}{c}\text { Mass } \\
\text { loading } \\
(\%)\end{array}$ & $\begin{array}{c}\text { BET } \\
\text { surface } \\
\left(\mathrm{m}^{2} / \mathrm{g}\right)\end{array}$ & $\begin{array}{c}\text { Half-lives } \\
\text { of NMNP } \\
\text { (min) }\end{array}$ & $\begin{array}{l}\text { Half- } \\
\text { lives of } \\
\text { GD } \\
\text { (min) }\end{array}$ & Ref. \\
\hline \multirow[t]{3}{*}{ MOF-808/PET } & \multirow{4}{*}{$\begin{array}{c}\text { template-free, } \\
\text { aqueous } \\
\text { synthesis }\end{array}$} & 6.5 & 130 & $<0.5$ & 2 & \multirow{4}{*}{$\begin{array}{l}\text { This } \\
\text { work }\end{array}$} \\
\hline & & 12 & 260 & $<1$ & & \\
\hline & & 22 & 480 & 3 & & \\
\hline UiO-66-NH $/ 2 / \mathrm{PET}$ & & 8 & 95 & 5 & 8 & \\
\hline $\begin{array}{c}\text { PA- } \\
\text { 6@ } \mathrm{TiO}_{2} @ \mathrm{UiO66}\end{array}$ & \multirow{2}{*}{$\begin{array}{l}\text { ALD oxides } \\
\text { templated } \\
\text { growth in } \\
\text { DMF }\end{array}$} & 8.8 & 144 & 135 & 3 & \multirow[t]{2}{*}{1} \\
\hline $\begin{array}{c}\text { PA- } \\
\text { 6@ } \mathrm{TiO}_{2} @ \mathrm{UiO67}\end{array}$ & & 14.7 & 356 & 7 & 3.7 & \\
\hline
\end{tabular}




\begin{tabular}{|c|c|c|c|c|c|c|}
\hline $\begin{array}{c}\text { PA- } \\
\text { 6@ } \mathrm{TiO}_{2} @ \text { UiO66- } \\
\mathrm{NH}_{2}\end{array}$ & & 15.4 & 206 & 7.3 & 2.3 & \\
\hline $\begin{array}{c}\mathrm{PP} / \mathrm{ZnO}+ \\
\mathrm{UiO}-66-\mathrm{NH} 2\end{array}$ & $\begin{array}{l}\text { ALD oxide } \\
\text { assisted } \\
\text { assembly in } \\
\text { DMF }\end{array}$ & 30.7 & 211 & 6.5 & & 2 \\
\hline $\begin{array}{c}\text { PP@ZnO@UiO- } \\
66-\mathrm{NH}_{2}\end{array}$ & $\begin{array}{l}\text { ALD oxides } \\
\text { templated } \\
\text { growth in } \\
\text { DMF }\end{array}$ & 15 & 145 & 10 & & 3 \\
\hline $\begin{array}{c}\text { MOFabric UiO- } \\
66-\mathrm{NH}_{2}\end{array}$ & $\begin{array}{l}\text { Impregnation } \\
\text { during } \\
\text { electrospinning }\end{array}$ & 33 & 225 & 12 & & 4 \\
\hline
\end{tabular}

\section{Reference}

1) Zhao, J.; Lee, D. T.; Yaga, R. W.; Hall, M. G.; Barton, H. F.; Woodward, I. R.; Oldham, C. J.; Walls, H. J.; Peterson, G. W.; Parsons, G. N. Angew. Chem. Int. Ed. 2016, 55, 13224.

2) Lee, D. T.; Zhao, J. J.; Gregory W. P.; Gregory N. P. Chem. Mater. 2017, 29, 4894.

3) Lee, D. T.; Zhao J.; Oldham C. J.; Peterson, G. W.; Parsons, G. N. ACS Appl. Mater. Interfaces 2017, 9, 44847.

4) Lu A. X.; McEntee M.; Browe M. A.; Matthew A. B.; Morgan G. H.; Jared B. D.; Gregory W. P. ACS Appl. Mater. Interfaces 2017, 9, 13632. 